Криворучко О. П., аспірант (Національний університет водного господарства та природокористування, м. Рівне)

\title{
РОЗВИТОК ДОРОЖНЬОЇ ГАЛУЗІ УКРАЇНИ ЧЕРЕЗ РЕАЛІЗАЦІЮ ІНВЕСТИЦІЙНО-ІНФРАСТРУКТУРНИХ ПРОЕКТІВ
}

В статті розглянуто теоретичні і практичні аспекти розвитку транспортного сектору економіки України. Наведено та проаналізовано модель впливу інвестицій в транспорту систему на економічне зростання. Розглянуто сучасний процес формування ефективного конкурентоспроможного ринку транспортних послуг та побудови збалансованої за видами транспорту транспортної системи. Визначено принципи електронного справляння плати за користування дорогами.

Ключові слова: інвестиційно-інфраструктурні проекти, електронна плата, дорожня галузь, електронне справляння плати.

Вступ. Однією з передумов ефективного функціонування й зростання національної економіки є високий рівень розвитку її інфраструктури. Потреба у відновленні та розвитку дорожньої мережі постійно зростає. Проте проекти, спрямовані на розвиток і вдосконалення інфраструктури, є досить фінансово затратними і не завжди ефективними. На даний час Україна потребує серйозних заходів та реформ, спрямованих на підвищення як загальних умов ведення логістики: показників діяльності митниці, поліпшення інфраструктури, міжнародних поставок, розширення спроможності відстежувати поставки та підвищення компетентності операторів послуг логістики, так і окремих секторів, насамперед дорожнього та залізничного: підвищення їх ефективності та забезпечення функціонування на стійкій фінансовій основі.

Аналіз публікацій. Теоретичним та практичним аспектам перспективного розвитку транспортного сектору економіки приділяється багато уваги у науковій літературі, що пов'язано з необхідністю забезпечення ефективної роботи національної транспортної системи у період відновлення економічного зростання, глобалізації світового виробництва та міжнародної торгівлі. Проблеми розвитку транспортного сектору економіки висвітлено в роботах вітчизняних і зарубіжних вчених: В.Брагінського, Ю. Цвєтова, М. Макаренко, Г. Ейтутіс, О. Котлубай, А. Филипенко та В. Баришнікова, А. Новікова і Т. Блудо- 
ва, В. Балін, Д. Козаченко, Ю. Мельник, І. Приходько, О. Філіпенко та інших.

Мета статті. Проаналізувати теоретичні і практичні аспекти розвитку транспортного сектору економіки України, та визначити принципи електронного справляння плати за користування дорогами.

Основний розділ. Наприкінці 2016 р. Міністерством інфраструктури України спільно з проектом технічної допомоги Європейського Союзу «Підтримка імплементації Угоди про асоціацію та Національної транспортної стратегії в Україні» проведено круглий стіл з питань оновлення Національної транспортної стратегії України до 2030 року [1]. У рамках заходу громадськості презентовано концепцію Національної транспортної стратегії (НТC) до 2030 року, обговорення якої виявило доцільність підключення до формування основних її положень, думок та пропозицій експертів, науковців та представників бізнесу.

Зважаючи на це, доцільно запропонувати підхід до формування оновленої НТС України. В основу Транспортної стратегії України закладена система змішаних (мультимодальних) перевезень. Основною метою даної стратегії $€$ забезпечення збалансованого розвитку різних видів транспорту зі збереженням провідної ролі в перевезенні великогабаритних і масових вантажів залізничним транспортом та розвиток мережі автомобільних доріг для перевезення товарів більш високої цінності. Це забезпечить максимальний потенціал реалізації Угоди про асоціацію між Україною та Європейським Союзом та Угоди про глибоку та всеосяжну зону вільної торгівлі, стимулювання розвитку вітчизняного сільського господарства та промисловості.

Одним із цільових напрямків є поліпшення забезпечення, транспортних зв'язків, експлуатації автомобільних доріг та безпеки доріг для їх користувачів та удосконалення управління мережею автомобільних доріг в Україні шляхом здійснення інвестицій у модернізацію мереж автомобільних доріг - реалізації інвестиційних інфраструктурних проектів. У короткостроковій перспективі залучення інвестиційних коштів сприятиме стабілізації дорожнього сектору шляхом надання необхідних коштів на утримання доріг з огляду на незадовільний фінансовий стан транспортної галузі. У середньостроковій та довгостроковій перспективі - економічному зростанню та підвищенню конкурентоспроможності, за рахунок зміцнення зв'язків між регіонами, покращення транзитних коридорів, що сприятиме активізації економічної діяльності шляхом скорочення тривалості поїздок і зниження витрат на перевезення між основними центрами в Україні та їхніми регіональними торговельними партнерами. При цьому, поліпшена дорожня інфраструктура забезпечить збільшення продуктив- 
них інвестицій у територіальні громади, що є бенефіціарами інвестиційних інфраструктурних проектів, і створення робочих місць для їх мешканців, а це сприятиме зростанню доходів домогосподарств і рівнів споживання, а також зниження рівня бідності [2].

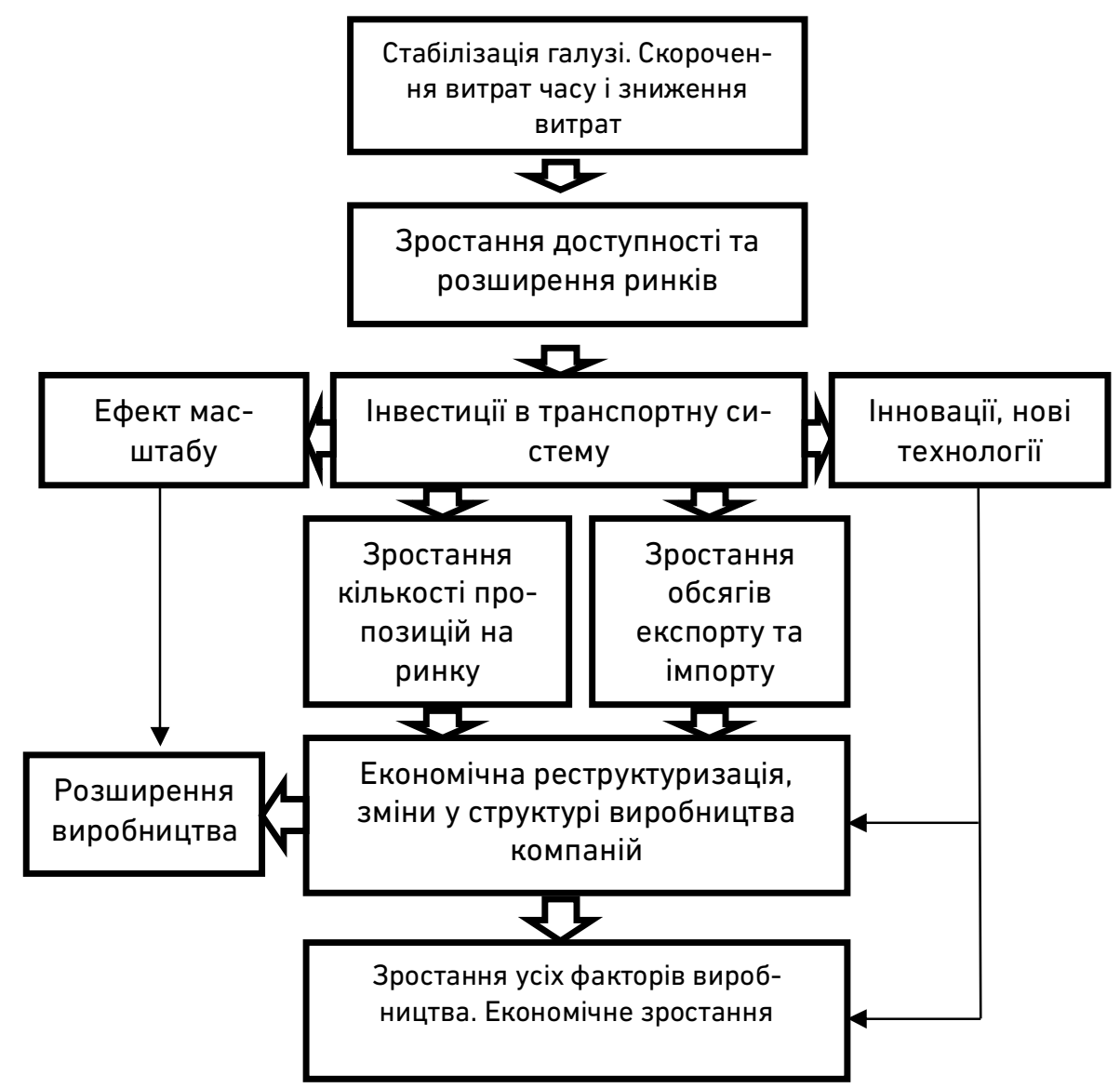

Рисунок. Модель впливу інвестицій в транспортну систему України для економічного зростання [3]

Інвестиції в транспортну систему, в тому числі і в транспортну інфраструктуру, в перспективі вплинуть на зростання обсягів реального ВВП на одну людину, завдяки зростанню активів суб'єктів ринку, виходу на нові ринки, що збільшує обсяги реалізації та дохідність їх діяльності [3].

Сучасний процес формування ефективного конкурентоспроможного ринку транспортних послуг та побудова збалансованої за видами транспорту транспортної системи вимагає фокусування:

1) на створенні мережі логістичних центів та інституту операторів мультимодальних перевезень - перерозподіл правової відпові- 
дальності між усіма учасниками транспортного ринку (адаптація законодавства України до законодавства $Є$ ): поетапне розмежування пасажирського та вантажного залізничного руху; імплементація дієвого механізму залучення коштів на реалізацію інвестиційних проектів, в тому числі будівництва швидкісних автомобільних доріг; урегулювання питань взаємодії учасників з міжнародними фінансовими організаціями, банками, приватними інвесторами;

2) розвитку інформаційних систем, інфраструктури транзитних перевезень та митних технологій, а саме прискорення гармонізації митних процедур (Кіотська конвенція, Конвенція про спільну транзитну процедуру) на основі принципу «єдиного вікна» при митному оформленні імпорту, експорту і транзиту в Україні (рекомендації та стандарти ЄЕК ООН, Всесвітньої митної організації) та уніфікованої системи національних правил організації змішаних транспортнотехнологічних і транспортно-логістичних схем перевезень вантажів за участю всіх видів транспорту;

3) використання державно-приватних партнерств - утворення спільних підприємств, розвиток механізмів концесій, укладання договорів про спільну діяльність, лізинг та інших за участю провідних європейських компаній [4].

Інвестиційний інфраструктурний проект $€$ проектом фінансування інвестиційних проектів за рахунок позики МБРР. За рахунок позики МБРР фінансується 100 відсотків прийнятих видатків, включаючи податок на додану вартість (ПДВ) та витрати на придбання земельних ділянок.

До 2015 року Бюджетний кодекс України та Закони про державний бюджет передбачали накопичення у спеціальному фонді Державного бюджету України відповідних зборів, податків і платежів. В подальшому ці доходи передавалися до Державного дорожнього фонду, із якого здійснювалися видатки на будівництво, реконструкцію, ремонт та обслуговування доріг. 32015 року відбулися радикальні зміни в підходах до бюджетного фінансування, за якими Укравтодор фінансується безпосередньо з загального фонду державного бюджету без закріплення податків та зборів з користувачів за спеціальним фондом. Без чітко вираженої політики фінансування дорожньої галузі це призвело до складнощів у плануванні покращення та утримання мережі доріг через відсутність інформації про ймовірні обсяги фінансування [1]. Огляд цільової програми з розвитку дорожнього господарства України на 2013-2018 роки наведено у таблиці. 
Таблиця

Програма розвитку доріг загального користування (млн грн) [2; 5]

\begin{tabular}{|c|c|c|c|c|c|c|}
\hline \multirow{2}{*}{ Вид діяльності } & \multicolumn{6}{|c|}{ Роки } \\
\hline & 2013 & 2014 & 2015 & 2016 & 2017 & 2018 \\
\hline $\begin{array}{l}\text { I. Будівництво та } \\
\text { реконструкція }\end{array}$ & 6138 & 5727 & 9108 & 11114 & 11599 & 12142 \\
\hline $\begin{array}{l}\text { 1. Дороги загального ко- } \\
\text { ристування }\end{array}$ & 4167 & 3744 & 5733 & 7976 & 8755 & 9145 \\
\hline 2. Об"їзні дороги & 1527 & 1109 & 2300 & 1089 & 875 & 648 \\
\hline $\begin{array}{l}\text { 3. Дороги місцевого } \\
\text { значення }\end{array}$ & 198 & 198 & 140 & 1249 & 1361 & 1653 \\
\hline $\begin{array}{l}\text { 4. Споруди, пошкоджені } \\
\text { повенями }\end{array}$ & 53 & 141 & 394 & 354 & 55 & 0 \\
\hline 5. Під"їзні шляхи & 9 & 299 & 298 & 248 & 363 & 519 \\
\hline $\begin{array}{l}\text { 6. Проектно- } \\
\text { вишукувальні роботи }\end{array}$ & 184 & 236 & 243 & 198 & 190 & 177 \\
\hline II. Капітальний ремонт & 3238 & 2670 & 3364 & 6850 & 7040 & 5451 \\
\hline $\begin{array}{l}\text { 7. Дороги зе } \\
\text { жавного зн }\end{array}$ & 3137 & 2280 & 2592 & 5727 & 5494 & 3904 \\
\hline $\begin{array}{l}\text { 8. Дороги місцевого } \\
\text { значення }\end{array}$ & 101 & 390 & 772 & 1123 & 1546 & 1547 \\
\hline $\begin{array}{l}\text { III. Періодичний } \\
\text { ремонт }\end{array}$ & 7739 & 9211 & 7733 & 6300 & 6592 & 6271 \\
\hline $\begin{array}{l}\text { 9. Дороги загальнодер- } \\
\text { жавного значення }\end{array}$ & 6726 & 5445 & 3943 & 2955 & 2577 & 2443 \\
\hline $\begin{array}{l}\text { 10. Дороги місцевого } \\
\text { значення }\end{array}$ & 1013 & 3766 & 3790 & 3345 & 4015 & 3828 \\
\hline IV. Поточний ремонт & 4153 & 6058 & 4738 & 4823 & 4290 & 4290 \\
\hline 11. Поточний ремонт & 4153 & 6058 & 4738 & 4823 & 4290 & 4290 \\
\hline V. Дослідження & 203 & 365 & 394 & 356 & 367 & 381 \\
\hline 12. Дослідження & 203 & 365 & 394 & 356 & 367 & 381 \\
\hline VI. Погашення позик & 7501 & 8108 & 8797 & 9915 & 9976 & 10569 \\
\hline 13. Погашення позик & 7501 & 8108 & 8797 & 9915 & 9976 & 10569 \\
\hline Bcboro & 28972 & 32139 & 34134 & 39358 & 39864 & 39104 \\
\hline $\begin{array}{l}\text { Всього без погашення } \\
\text { позик }\end{array}$ & 21471 & 24031 & 25337 & 29443 & 29888 & 28535 \\
\hline
\end{tabular}

Високий рівень витрат на обслуговування доріг безпосередньо пов'язаний зі шкодою, якої завдають перевантажені вантажівки. За неофіційними оцінками більш ніж $80 \%$ усіх вантажних автомобілів в Україні рухаються 3 перевищенням максимально допустимої маси. Належне застосування систем контролю на кшталт систем зважування в русі, що супроводжуватиметься ефективними заходами та переконливими штрафами, потенційно може забезпечити суттєве зниження витрат на експлуатацію.

Іншою суттєвою проблемою, що ускладнює процес планування, 
$€$ відсутність достовірної та актуальної інформації про стан доріг надійної системи управління якістю дорожнього покриття.

Для зниження витрат загальної суми витрат необхідно впроваджувати ефективну конкуренцію при укладанні договорів як на виконання робіт на замовлення інститутів Укравтодору, так і з обласними дорожніми службами. Для цього необхідно змінити середовище укладання договорів в сторону централізації або укрупнення учасників процесу закупівлі (об'єднання кількох лінійних підрозділів 3 експлуатації доріг у територіальні об'єднання, укладання договорів на збільшені території на кілька років, централізована закупівля у формі невеликої кількості лотів, кожний із яких охоплював би по кілька областей).

Альтернативним джерелом фінансування утримання доріг та поліпшення фінансового стану дорожньої галузі може бути електронне справляння плати за користування дорогами.

Електронне справляння плати за користування дорогами у формі дистанційного справляння плати, головним чином, із вантажного автотранспорту, розглядається як розумний і справедливий спосіб розподілу витрат між користувачами доріг. Розвиток технологій споживчого ринку та транспорту забезпечує засобами зв'язку і транспорт, і людей, створюючи тим самим нові шляхи для оплати послуг та подальшого зниження витрат [1].

При впровадженні електронного справляння плати за користування дорогами є кілька проблем, здатних ослабити чи унеможливити впровадження даної системи:

1. Види транспортних засобів. Виділяють дві цільових групи користувачів, які подорожують у різних обсягах, різною інтенсивністю, мають різні потреби, очікування та спроможності до внесення плати: вантажні транспортні засоби, дозволена маса яких перевищує 3,5 т. та решта автомобілів (головним чином легкові).

2. Мережа доріг. Необхідно визначити прийнятний рівень охоплення платою мережі доріг: деякі магістралі чи всі дороги загальнодержавного значення. Оскільки, рівень охоплення платою доріг не тільки впливає на надходження й видатки, але й справляє вплив на інтенсивність руху, на стан доріг, тягне за собою соціальноекономічні наслідки, впливає на утримання парку транспортних засобів.

3. Технологія справляння плати. Для справляння плати за користування дорогами необхідно внести чимало змін до законодавства. Інституційна структура має забезпечувати ефективну взаємодію різних організацій, юридичних осіб публічного та приватного права.

Висновки. Реалізації інвестиційних інфраструктурних проектів 
має бути підпорядкована завданням структурної перебудови галузі транспорту, спрямована на забезпечення збалансованого і гармонійного розвитку всіх ланок комплексу, на оновлення виробничого потенціалу, підвищення ефективності його використання. Для подальшого розвитку галузі транспорту необхідно концентрувати інвестування на впровадження високопродуктивних та новітніх інноваційних та інформаційних технологій, оновлення й модернізації основних фондів та об'єктів інфраструктури.

Забезпечення сприятливого інвестиційного клімату залишається питання стратегічної важливості, від реалізації якого залежить ефективність реалізації заходів економічного зростання економіки України, ефективність реалізації інвестиційних проектів, можливість модернізації галузі транспорту. Формування сприятливого інвестиційного клімату повинно відбуватися як на макро-, так і на регіональному рівні, оптимізації цілої сукупності політичних, правових, економічних, соціальних, екологічних, організаційних, інформаційних, галузево- та регіонально-специфічних факторів.

1. Матеріали круглого столу з питань оновлення Національної транспортної стратегії України до 2030 року. URL : http://mtu.gov.ua/content/krugliy-stilzpitan-onovlennya-nacionalnoi-transportnoi-strategii-ukraini-do-2030roku.html. (дата звернення: 15.11.2018). 2. Державне агентство автомобільних доріг України. Проект розвитку дорожньої галузі. Інструкція про діяльність у рамках проекту. $2016 . \quad$ URL: http://ukravtodor.gov.ua/timeline/publichna_informatsiia.html (дата звернення: 15.11.2018). 3. Шиба О. А. Стратегія розвитку транспортної інфраструктури України в умовах євроінтеграції. URL: http://bses.in.ua/journals/2016/8-2016/9.pdf (дата звернення: 15.11.2018). 4. Дашкуєв М. А. Сучасний стан процесу інтеграції транспортно-логістичної системи України в європейський субрегіональний простір 2015. URL: http://www.business-inform.net/export_pdf/business-inform-2015-5_0pages-133_140.pdf (дата звернення: 15.11.2018). 5. Road Sector Diagnostic Report («Звіт про діагностику дорожньої галузі»), HPR, квітень 2015 року. URL : http://ukravtodor.gov.ua/4489/zvity/rezultaty_provedennia_ finansovoho_audytu_proektu_druhyi_proekt_pokrashchennia_avtomobilnykh_d orih_ta_bezpeky_rukhu.html (дата звернення: 15.11.2018).

\section{REFERENCES:}

1. Materialy kruhloho stolu z pytan onovlennia Natsionalnoi transportnoi stratehii Ukrainy do 2030 roku. URL : http://mtu.gov.ua/content/krugliy-stilzpitan-onovlennya-nacionalnoi-transportnoi-strategii-ukraini-do-2030-

roku.html. (data zvernennia: 15.11.2018). 2. Derzhavne ahentstvo 
avtomobilnykh dorih Ukrainy. Proekt rozvytku dorozhnoi haluzi. Instruktsiia pro diialnist u ramkakh proektu. $2016 . \quad$ URL: http://ukravtodor.gov.ua/timeline/publichna_informatsiia.html (data zvernennia: 15.11.2018). 3. Shyba 0. A. Stratehiia rozvytku transportnoi infrastruktury Ukrainy $v$ umovakh yevrointehratsi. URL: http://bses.in.ua/journals/2016/8-2016/9.pdf (data zvernennia: 15.11.2018). 4. Dashkuiev M. A. Suchasnyi stan protsesu intehratsii transportnolohistychnoi systemy Ukrainy $v$ yevropeiskyi subrehionalnyi prostir 2015. URL: http://www.business-inform.net/export_pdf/business-inform-2015-5_0pages-133_140.pdf (data zvernennia: 15.11.2018). 5. Road Sector Diagnostic Report («Zvit pro diahnostyku dorozhnoi haluzi»), HPR, kviten 2015 roku. URL : http://ukravtodor.gov.ua/4489/zvity/rezultaty_provedennia_

finansovoho_audytu_proektu_druhyi_proekt_pokrashchennia_avtomobilnykh_d orih_ta_bezpeky_rukhu.html (data zvernennia: 15.11.2018).

Рецензент: д.е.н., професор Савіна Н. Б. (НУВГП)

Kryvoruchko 0. P., Post-graduate Student (National University of Water and Environmental Engineering, Rivne)

\section{DEVELOPMENT OF THE ROAD SECTOR OF UKRAINE THROUGH IMPLEMENTATION OF INVESTMENT-INFRASTRUCTURE PROJECTS}

The article considers theoretical and practical aspects of the transport sector development of the Ukrainian economy. It is determined that one of the prerequisites for the effective functioning and growth of the national economy is the high level of its infrastructure development. And the need for renewal and development of the road network is constantly increasing. It is determined that at present, Ukraine needs serious measures and reforms aimed at improving both general logistics conditions: customs performance indicators, infrastructure improvements, international supply, increased ability to track deliveries and increase the competence of logistics service providers, as well as individual sectors, in the first turn of the road and rail: improving their efficiency and ensuring functioning on a stable financial basis.

The model of the investment impact in the transport system on economic growth is given and analyzed. One of the target areas is to improve the provision of transport links, operation of roads and road safety for their users and improve the management of the network of roads in Ukraine by investing in the modernization of the networks of roads - the implementation of investment infrastructure projects. 
The modern process of an effective competitive market of transport services formation and the contraction of the balanced transport system by transport types are considered. The Budget Code of Ukraine and the laws on the state budget provided for the accumulation in the special fund of the State Budget of Ukraine of relevant fees, taxes and payments. Subsequently, these revenues were transferred to the State Road Fund, from which expenditures on construction, reconstruction, repair and maintenance of roads were carried out. Since 2015, there have been radical changes in the approaches to budget financing, which Ukravtodor is financed directly from the general fund of the state budget without the imposition of taxes and fees from users under the special fund. Without a clear-cut policy of financing the road sector, this has led to difficulties in planning for improving and maintaining a network of roads due to the lack of information on likely financing levels.

The electronic charging mechanisms for the roads use are defined. When introducing e-commissioning fees for using roads, there are several problems that can weaken or prevent the introduction of this system.

Keywords: investment and infrastructure projects, electronic payment, road industry, electronic charging mechanisms.

Криворучко Е. П., аспирант (Национальный университет водного хозяйства и природопользования, г. Ровно)

\section{РАЗВИТИЕ ДОРОЖНОЙ ОТРАСЛИ УКРАИНЫ ЧЕРЕЗ РЕАЛИЗАЦИЮ ИНВЕСТИЦИОННО-ИНФРАСТРУКТУРНЫХ ПРОЕКТОВ}

В статье рассмотрены теоретические и практические аспекты развития транспортного сектора экономики Украины. Приведена и проанализирована модель влияния инвестиций в транспортную систему на экономический рост. Рассмотрен современный процесс формирования эффективного конкурентоспособного рынка транспортных услуг и построения сбалансированной по видам транспорта транспортной системы. Определены принципы электронного взимания платы за пользование дорогами.

Ключевые слова: инвестиционно-инфраструктурные проекты, электронная плата, дорожная отрасль, электронное взимания платы. 